\title{
E-Learning Management System Model for Thai Society
}

\author{
Jiracha Vicheanpanya
}

\begin{abstract}
The purpose of this study are to develop, verify and approve the e-Learning management system model for Thai society. The research methodology was qualitative method that carried out using semi-structure interview questions for in-depth interview the experts and executives in e-Learning of academic institutions including government sectors and focus group with a specialist in e-Learning of the meeting Committee on Science, Technology and Telecommunications of the Thai Senate. The research found that the e-Learning management system model for Thai society has three main components; firstly, general management, secondly, e-Learning management system, and lastly, e-Learning management-driven strategy for Thai society.
\end{abstract}

Index Terms-E-Learning, e-learning management system model, Thai society.

\section{INTRODUCTION}

Thailand focuses on the development of education especially in the "developing people" area. This is the heart of the National Economic and Social Development Plan as it is shown in the National Education Act 1999, as amended (No. 2) Act 2002. It is considered a foundation of the educational reform of Thailand that states the importance of education reform that consists of the rights and equal opportunities for education for all target groups of learners regardless of gender, age, class, able and disable. The process of education must be a lifelong learning experiences allowing all people of all societies take part in the education and learning consistently and continuously. The educational technology is now considered a factor that contributes to the success of the educational reforms in many aspects such as educational administration, teacher and educational personnel development [1], [2].

\section{LITERATURE REVIEW}

The development of information technology in education refers to the development and application of information and knowledge that supports learning with a learning-centered approach. This develops the human resource for quality and moral as a tool to reduce inequality access to education and learning services. It also supports the development of learning society regarding the effectiveness of management and reducing the duplication of investment, production of quality educational content and the usage of educational technology for diversity achievement [3].

Manuscript received May 25, 2013; revised September 18, 2013. This work was supported by the Secretariat of the Senate, Thailand.

J. Vicheanpanya is with the Faculty of Communication Arts, Rangsit University, Paholyotin Rd., Patumtani 12000, Thailand (e-mail: jiracha.v@rsu.ac.th, ajjoy50@gmail.com).

\section{A. Educational Direction and Policy in Thailand}

The National Education Act 1999 in section 6 had defined that educational administration must be to develop Thai people for a complete human by physical, mental, intellectual, knowledge and moral, ethical and cultural for coexist living with others happily by regarding to the principles of educational administration in three dimensions as follows; lifelong learning for people, the social participation in education and development of content and learning processes continuously based on the educational guideline that states that all learners have the abilities to learn and develop themselves. The learner is considered the utmost important one and educational processes must be to promote the natural learning development to achieve their full potential [2].

Educational technology as defined in section 64 that "The State shall promote and encourage to develop and produce the textbooks, academic books, printed materials, and other educational technologies by precipitate of production capacity development. This should include financial providence and incentives to producers by allowing free and fair competition to take place. The State shall also promote for research and development in educational technology including monitoring and evaluating of the use of educational technology to achieve cost-effective learning process of Thai people. The mentioned strategies for development of information technology in education consists of six strategies as the followings; policy administration and management efficiency, the development of information infrastructure for education, human resources development, the development of educational material and creating knowledge, creating an equality of access and use the educational materials for learning and creating a learning network [2], [3].

\section{B. E-Learning}

E-Learning refers to a model of learning through computer network via the Internet or intranet with electronic learning medias diverse as character, slide, animation, video and sound by using of web technology to convey education materials including use the Learning Management System LMS) to increase the capability of teaching, communication, monitoring and evaluation of student learning effectively. The students can learn based on their own interest and an active support learning environment. The learner is a creator of their own new knowledge and understanding of their learning process and can be linked to real life through various networks [4]-[6].

The main characteristics of e-Learning with the use of the resources in the internet system design and organize the learning system. It supports and promotes learning in a meaningful way to meet the needs of lectures and learners which can be linked to the system via networks so that one 
can learn anytime and anywhere. It provides virtual learning environment to the real classroom. The elements of e-Learning comprised of lessons, learning management system, communications, and examination and assessment. [4]-[6]. Learning Management System: LMS is a computer program is used to manage the learning process of the students such as registration, tracking of the individual learning progress, testing, assessment and evaluation, and report the learning score. The system can also be used as a communication link between the student and the instructor in each course including support for activities in the online learning environment. The whole function of the LMS system is easy to use, friendly, and single user-interface. There are ten main functions as follows; administration, organizational management, time management, reporting, needs analysis, preplanning, scheduling, knowledge management, resources planning, and qualification management [6]-[8].

\section{RESEARCH QueSTION AND RESEARCH OBJECTIVE}

Research question: What should be the e-Learning management system model for Thai society?

Research objective:

1) To develop the e-Learning management system model for Thai society.

2) To verify and approve the e-Learning management system model for Thai society.

\section{RESEARCH METHODOLOGY}

Key informants: The main contributors of the collection of qualitative data have two groups. The first group is 5 experts and executives in e-learning of academic institutions including government sectors to collect the data concerning the status and trends of e-learning development in Thai society, the development of learning management system and content of the education and learning management in Thai society. The second group is 25 the executives and specialists in e-learning of the education and learning management of the meeting Committee on Science, Technology and Telecommunications of the Thai Senate to discuss and brainstorm together to recommendation, verify, and approve the model of the e-Learning management system for Thai society.

Instrument used for data collection: The researcher uses semi-structure interview questions for in-depth interview and focus group.

Data collection: The primary data is collected directly from the source or origin of the research by in-depth interviews and focus group with the executives, experts and administrators in e-learning. The secondary data is collected by reference from another person various sources such as libraries, information centers, website and other institutions.

Data analysis: The researcher will rely upon content analysis and construct conclusion by inductive method by using typological analysis, domain analysis, and conclusion key elements of e-Learning management system model for Thai society. Finally, verified and approved the e-Learning management system model for Thai society by the meeting
Committee on Science, Technology and Telecommunications of the Thai Senate.

\section{RESEARCH RESULTS}

The e-Learning management system model for Thai society has three main components; firstly, general management, secondly, e-Learning management system, and lastly, e-Learning management-driven strategy for Thai society (see Fig. 1)

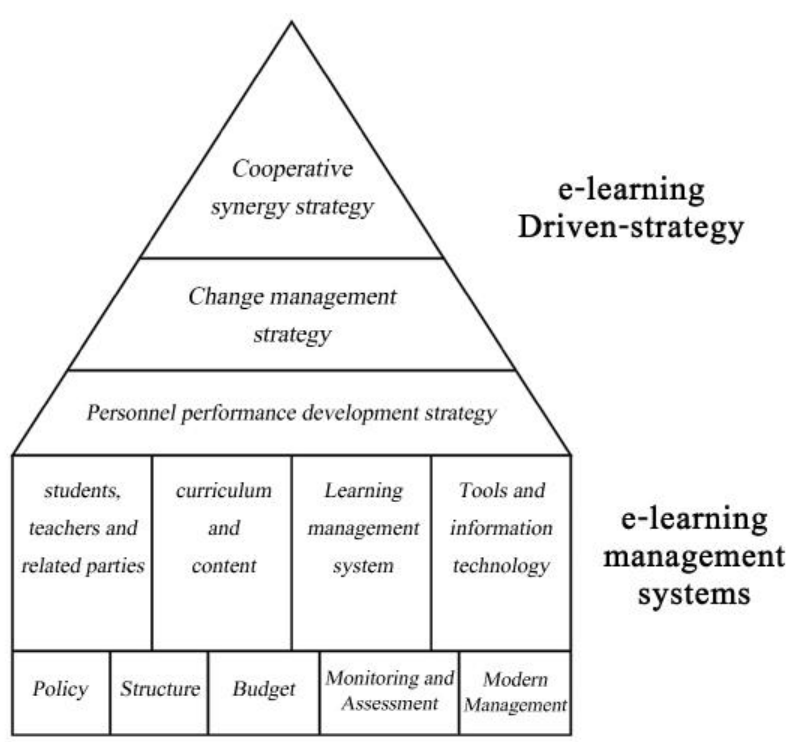

General management

Fig. 1. E-Learning management system model for Thai society.

The objective of e-Learning management system model for Thai society is to compel national e-learning management system that will become united in terms of policy and operation in order to move forward as knowledge-base society with good quality and under international standard.

The policy and strategic goal of e-Learning management system model in Thai society is as follows;

1) To have an independent central agency responsible for and manage national e- Learning system so that it will become united

2) To promote and compel cooperation in developing subsystems under the working group involved with national e-Learning management.

3) To have a compel strategy that will drive e-learning cooperation in Thai society in a substantial manner.

\section{A. General Management System}

General management System comprise of management in the aspects of 1) policy 2) structure 3) budget 4) monitoring and assessment and 5) modern management. They are as follows:

Policy: there should be an independent central organization or a public organization called "National Technology Institute for Education" to take the responsibility for e-Learning management in form of an associate member or consortium. This organization will promote, support coordinate and compel the use of technology for education in Thailand, provide technology service for national education, organize activity in form of coordination center for academic research and development. It also conducts other activities in 
order to exchange knowledge and create performance monitoring mechanism or system.

Structure: there are 3 levels of management including national, associate member and operational levels, whereby a director will be the main person in charge of the institute. There should be a steering committee in form of associate member or consortium from all sectors to work together as different groups of committees. For example, 1) steering committee on strategy in driving and compelling e-learning in Thai society 2) steering committee on e-learning standard development 3) steering committee on infrastructure and information technology 4) steering committee on content and learning media production and 5) steering committee on support, promotion, supervision and assessment.

Budget: It should be partly supported by The state and partly from taxes collected from IT industries (entrepreneurs in computer, communication and telecommunication and other related businesses). Budget allocation should be in form of project-based support work that where there must be a system that will strictly monitor the use of budget, as well as clear indicators of the project that will deliver the work should be in place.

Monitoring and assessment: A variety of stages should be provided in order to publicize and pass on knowledge, and to report operational outcome to the public without considering productivity, operational outcome or impact that occurred as expected or not.

Modern management: Modern management of information technology should be emphasized such as concept of cloud computing management, risk management, and information security management. The concept of knowledge management and innovative management should be applied to learning management and e-learning management.

\section{B. E-Learning Management System}

E-Learning management system comprised of the management of 1) students, teachers and related parties 2) curriculum and content 3 ) learning management system and 4) tools and information technology. They are as follows;

With regard to students, teachers and related parties, the management will be focused on firstly clear categorization of all related parties so that management and service can be easily carried out. Secondly, the provision of education in form of "research and development" by studying the behavior in using knowledge and learning need of users in different groups is used to develop learning resource and delivering knowledge in responses to behavior and learning need of those groups. Thirdly placing more importance on students who are knowledgeable in public, state enterprise, private social and community organizations in order to develop a variety of knowledge and professional skills, and create competitive advantage and support the work in international level.

Significant curriculum and content are as follows:

1) Standard: The focus should be on the preparation of standard, guideline or process in developing curriculum and content under international standard, supporting the development of online lesson with good quality and under international standard such as SCORM or Metadata, and developing component standard of content in order to use as criteria assessing quality for contents of all types and levels.

2) Courseware development: The focus should be on the promotion of courseware development for the underprivileged in Thai society especially the development of beneficial and valuable course of the Thai language, giving opportunity for private sectors to invest in content or courseware production in order to promote quality competition.

3) Support extensive use of learning courseware: The focus should be accessible online as national learning repository and be used for further development learning access. The portal will include information that can be linked to variety of learning sources.

Learning management system: The focus should be on 1) developing standard or common requirement of instructional management system to be used as a guideline in developing lessons, providing service and sharing or using learning resources 2) promoting the development of content management system in form of ready-made system which is easy and convenient for document and knowledge management in various formats and 3) maximizing system capacity by applying knowledge management concept to learning process in which modern technology can be used such as wiki online or other online social media as to promote various forms of learning including knowledge creation, knowledge sharing or communication and transmission of knowledge and experience.

Tools and information technology: The focus should be on 1) the use of technology called "Grid Computing" which has the capacity to accommodate the processing of vast amounts and complex data, and link, access and manage vast amounts of data effectively 2) supporting and promoting more extensive application of Thai OS so it can be another option in using economical and safe computer system, and can also resolve copyright issues and 3) enhancing learning capacity by utilizing more social networks such as Facebook, Twitter, Bloggang, etc.

\section{E-Learning Management-Driven Strategy for Thai Society}

E-Learning management-driven strategy for Thai society comprised of 1) personnel performance development strategy 2) change management strategy and 3) cooperative synergy strategy as follows;

Personnel performance development strategy will be focusing on 1) developing the capacity of students with characteristics that contribute to the success of e-learning. For example, students shall be initiative, enthusiastic for gaining knowledge and are able to learn and create knowledge by themselves and 2) developing the capacity of teachers so they will be able to develop content, knowledge and e-courseware with good quality and standard by themselves, and place more importance on adjusting their roles from being a person who transfer knowledge to a person who gives suggestion and assists students so they will become successful in learning.

Change management strategy will be focusing on 1) communicating in order to generate recognition and acceptance, as well as giving reward, which will be a motivation to the change of knowledge and learning behavior 
2) promoting recognition in different groups of students so they will be able to recognize and use beneficial and valuable information and knowledge from plenty of e-learning sources in Thai society and 3) protecting and guarding students from inexact and incorrect information by boosting their immunity and helping them to become cognizant of information and media that may be detrimental to young people's way of living.

Cooperative synergy strategy will be focusing on the participation and collaboration among all related parties including public, state enterprise, private or community levels. There are three main collaboration groups as follows: 1) developers of content, knowledge and related standard 2) users including students and teachers, and 3) service providers, etc.

\section{RESEARCH CONTRIBUTION}

Policy contribution: the research result of the policy contribution is a recommendation or guideline for determination of e-learning policy related to e-Learning management system in operations network and the standard of learning management system.

Operational contribution: the relevant institutions can be used the study of the research result for synergy in all dimensions effective.

\section{ACKNOWLEDGMENT}

We would like sincere appreciation thanks to the Secretariat of the Thai Senate for research funding and the
Committee on Science, Technology and Telecommunications of the Thai Senate for the research recommendation, verification, and approval the model of the e-Learning management system for Thai society.

\section{REFERENCES}

[1] Office of the National Economic and Social Development Board, The Ninth National Economic and Social Development Plan (2002-2006), Bangkok: NESDB, 2002.

[2] Office of the Education Council, The National Education Act 1999, Bangkok: OEC, 1999.

[3] Ministry of Information and Communication Technology, National ICT Policy Framework 2011-2020: ICT 2020, Bangkok: MICT, 2011.

[4] R. Mason and F. Rennie, E-learning and social networking handbook: resources for higher education, New York: Routledge, 2008.

[5] G. Conole and M. Oliver, Contemporary perspectives in e-learning. themes, methods and impact on practice, London: Routledge, 2007.

[6] M. J. Rosenberg, E-learning: strategies for delivering knowledge in the digital age, New York: McGraw-Hill, 2001.

[7] T. Laohajaratsang. (August 2005). LMS: Learning Management System. [Online]. Available: http://www.it.chiangmai.ac.th/issue2.php

[8] J. Putnam and J. B. Burke, Organizing and managing classroom learning communities, New York: McGraw-Hill, 1992.

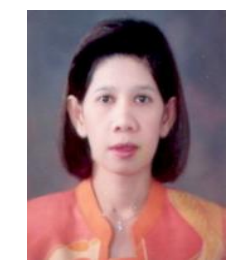

J. Vicheanpanya is a lecturer and a researcher at Department of Multimedia, Faculty of Communication Arts, Rangsit University, Thailand. She earned a Ph.D. in Educational Technology and Communications from Chulalongkorn University. Her main research areas are in the fields of knowledge management system (KMS), online learning, e-learning design and development and e-integrated marketing communication (e-IMC) 